\title{
GADOLINIUM RETENTION IN HUMANS: SURVEY OF RADIOLOGISTS AND IMPACT ON DAILY PRACTICE*
}

\author{
INSANDA GADOLINYUM BIRIKIMI: RADYOLOJI UZMANLARI VE KLINIK \\ UYGULAMALAR ÜZERINDEKI ETKISI
}

\author{
Mehmet Emin ADIN¹ (D), David Mark YOUSEM² (D) \\ YYale School of Medicine, Connecticut, USA, emin.adin@gmail.com \\ 2Johns Hopkins University School of Medicine, Maryland, USA
}

ORCID IDs of the authors: M.E.A. 0000-0002-0070-9998; D.M.Y. 0000-0002-1222-6643

Cite this article as: Adin ME, Yousem DM. Gadolinium retention in humans: survey of radiologists and impact on daily practice. $J$ Ist Faculty Med 2021;84(3):331-41. doi:10.26650/IUITFD.2021.874672

\begin{abstract}
Objective: We sought to assess the 1) awareness and impact of emerging gadolinium retention data on preferences of radiologists in their practice, and 2) factors that influence the attitudes about gadolinium use and risk. This study also documents various specifics of radiology practice in Turkey.
\end{abstract}

Methods: A twenty-one question survey was directed to radiologists who were at least one year from completion of residency and/or fellowship training. A survey link was emailed to the members of the Turkish Society of Radiology and was active for four weeks. The results were statistically analyzed.

Results: Three hundred and thirty-five radiologists completed the survey. At the time of this survey, $89 \%$ of respondents were aware of gadolinium retention in the brain. Forty-five percent of respondents said they decreased the amount of gadolinium administered and/or frequency of gadolinium-enhanced scans since the emergence of the gadolinium retention data. Eightyeight percent of radiologists, who were aware of the molecular classification of different gadolinium agents, used a macrocyclic agent. Thirty-nine percent $(n=130)$ had switched to a macrocyclic agent from a linear agent within the previous three years. Radiologists' attitudes toward gadolinium retention were significantly associated with their background factors such as experience in radiology, subspecialty training, and daily work definition, amongst others. Observence of hyperintense dentate nuclei due to gadolinium retention was uncommon in daily practice.

Conclusions: Gadolinium retention publications have affected the practice of contrast enhanced Magnetic resonance imaging (MRI) scans, mostly in the form of switching to a macrocyclic gadolinium agent and decreasing utilization of gadolinium in general for some indications. These changes varied among radiologists by background factors.

Keywords: Gadolinium, magnetic resonance imaging, surveys and questionnaires, radiologists, cerebellar nuclei

\section{ÖZET}

Amaç: Bu çalışmada, 1) Son yıllarda ortaya konulan, insan beyninde gadolinyum birikimi verileri hakkında radyologların farkındalığı, klinik uygulamaları ve tercihleri üzerindeki etkisi ve 2) Gadolinyum kullanımı ve riski hakkındaki yaklaşımları etkileyen faktörlerin değerlendirilmesi amaçlandı. Ayrıca bu çalışmada, Türkiye'deki radyoloji pratiği hakkında önemli bilgiler sunuldu.

Yöntem: İhtisas veya yan dal eğitiminin tamamlanmasından en az bir yıl geçmiş olan radyologlara yönelik 21 soruluk anket hazırlandı. Türk Radyoloji Derneği üyelerine e-posta ile gönderilen anket linki dört hafta boyunca aktifti.

Bulgular: Üç yüz otuz beş kişi anketi tamamladı. Katılımcıların \%89'u beyinde gadolinyum birikimi hakkındaki gelişmelerden haberdardı. Katılımcıların \%45'i gadolinyum birikimi verilerinin ortaya çıkmasından bu yana uyguladıkları gadolinyum miktarını ve/veya gadolinyum gerektiren görüntülemelerin sıklığını azalttığını söyledi. Gadolinyum ajanlarının moleküler sınıflandırmasının farkında olan radyologların \%88'i makrosiklik bir ajan kullandığını belirtti. Yüzde 39'u ( $n=130)$ önceki üç yıl içinde (2015-2018) lineer bir ajandan makrosiklik bir ajana geçtigini bildirdi. Radyologların gadolinyum birikimine yönelik yaklaşımı, radyoloji deneyimi, üst ihtisas eğitimi, kurumu ve bir radyoloji konferansına katılım sıklığı gibi kişiye özel faktörlerle önemli ölçüde ilişkiliydi. Katılımcıların günlük klinik pratikte gadolinyum birikimine bağlı gelişen hiperintens dentat nukleus gözlemleme sıklığı düşüktü.

Sonuç: Gadolinyum birikimi çalışmaları, radyologların MR görüntüleme pratiğini ve yaklaşımını, çoğunlukla makrosiklik gadolinyum ajanlarina geçiş ve gadolinyum kullanımını azaltmak suretiyle etkilemiştir. Bu değişiklikler, radyologların bireysel koşullarına göre değişiklik göstermektedir.

Anahtar Kelimeler: Gadolinyum, manyetik rezonans görüntüleme, anketler, radyoloji uzmanları, serebellar çekirdekler

* This study was presented at ECR 2020.

Corresponding author/iletişim kurulacak yazar: emin.adin@gmail.com

Submitted/Başvuru: 04.02.2021 • Revision Requested/Revizyon Talebi: 02.03.2021 •

Last Revision Received/Son Revizyon: 06.03.2021 • Accepted/Kabul: 08.03.2021 • Published Online/Online Yayın: 27.05 .2021 


\section{INTRODUCTION}

Since the original reports of intracranial gadolinium retention/deposition in 2014, a number of studies have been published that attribute Hyperintense Dentate Nuclei (HDN) on T1-weighted MR images to repeated administrations of intravenous gadolinium (1-8). The clinical ramifications of gadolinium deposition have been debated and not yet substantiated, but the possible unwanted outcomes have worried practitioners, patients, drug companies and government organizations (9-11). On the other hand, while alternative contrast agents are being investigated, gadolinium is still integral to many Magnetic resonance imaging (MRI) protocols $(12,13)$. Involvement of radiologists in study ordering, appropriateness of scan indication, optimum protocoling and patient engagement are among the new areas of emphasis on utilization (14-16). Despite the numerous publications and significant research activity around the potential impact of gadolinium retention in the human body, little is known about the impact of these initiatives on daily radiology practice. Practice diversity exists across the globe. This study was based in Turkey, a country where the majority of radiologists individually prescribe gadolinium for their patients prior to MRI scans. Thus, their personal preferences may have a direct impact on the landscape of gadolinium utilization. This is important, as the study was conducted in a period when there was no limitation on the utilization of linear gadolinium molecules in the market yet. In this regard, the aim of this study was two fold: 1) to assess the awareness and impact of emerging gadolinium retention data on the preferences of radiologists in their practice, and 2) analyze the factors that influence the attitudes about gadolinium use and risk.

\section{METHODS}

A survey was created using www.surveymonkey.com (San Mateo, CA) (see Appendix 1). The survey was anonymous with no personal information like name, sex, race, age or the name of the institution being asked, thus, as per ethical committee regulations, the study did not require IRB processing. All respondents read a written informed consent and agreed to participate prior to proceeding with the survey questions. Each question included a 'no response' choice to allow participants not to share their opinions. The survey was addressed to radiologists who were at least one year from completion of residency and/ or fellowship training. A closed survey link was emailed to the members of the Turkish Society of Radiology and a reminder email was sent two weeks later. The survey was active during four weeks (October-November 2018). The survey was set to allow only one individual response per device, to prevent repetitive responses. A total of 21 multiple-choice questions were asked. Participants were able to skip any question.
Statistical analyses were performed using SPSS version 21.0 for Windows (SPSS, Chicago, III). Descriptive statistics are presented. Decimals of percentages were rounded, as the actual numbers of samples ( $n$ ) were provided. Respondents were grouped according to types of institution, scope of daily radiology practice, experience in radiology, and frequency of their attendance at radiology conferences/meetings. Normality of the variables' dispersion was tested with the Kolmogorov-Smirnov test. Nonparametric Kruskal-Wallis H Test was used to test the difference between the groups, because all tested variables showed a non-Gaussian dispersion $(p<0.0001$ on Kolmogorov-Smirnov test for all variables). Groups were statistically analyzed and significant data for each subgroup are presented in a table (Table 1).

\section{RESULTS}

Three hundred and thirty-five members of Turkish Society of Radiology with at least one year of experience after radiology training completed the survey.

\section{Background of respondents}

Thirty-one percent $(n=103 / 335)$ of respondents were affiliated with government-run community hospitals, 48\% $(n=160)$ with academic institutions, and $21 \%$ were affiliated with a private practice $(n=64$ private hospital; $n=7$ imaging centers). Seventy-two percent $(n=242 / 335)$ of respondents defined their daily radiology practice as a general diagnostic radiology, $22 \%(n=72)$ as a diagnostic subspecialty, and $6 \%(n=21)$ as an interventional subspecialty. There was significant difference between participants' daily work definition based on their institution. Most of the community hospitals and private practice radiologists (94\% and $83 \%$, respectively) were performing general radiology as opposed to academic center radiologists $(53 \%,(p<0.0001))$. $50 \%(n=167)$ of respondents were 1 to 5 years from their previous training period (either fellowship or residency), $19 \%(n=63)$ were 5 to 10 years, $10 \%(n=33)$ were 10 to 15 years, and $20 \%(n=67)$ were more than 15 years after their training period. Thirty-six percent $(n=122)$ of respondents attended a radiology conference less frequently than once a year, 30\% $(n=101)$ attended once a year, and 30\% $(n=100)$ attended more frequently than once a year with $2 \%(n=5)$ attending conferences at least once a month. Forty-two percent of general radiology practitioners were attending a scientific conference less frequently than a year, as opposed to subspecialists and interventional radiologists (25\% and $10 \%$, respectively $(p=0.02)$ ).

\section{Awareness of radiologists and adoption in clinical practice}

Twenty-two percent $(n=84)$ did not know the class (macrocyclic or linear) of gadolinium agent they used. Twenty-six percent $(n=86)$ were using a macrocyclic gadolinium 


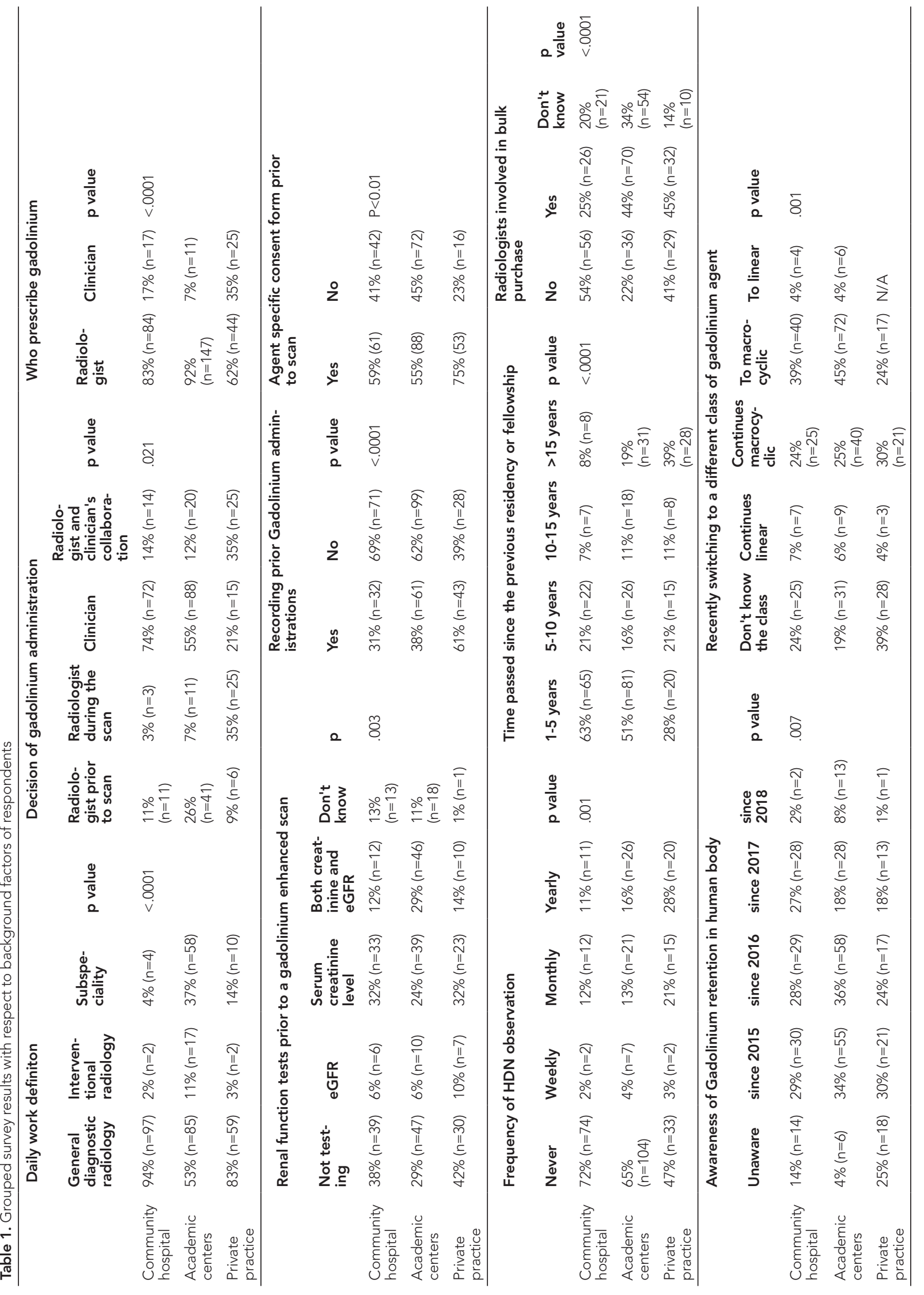




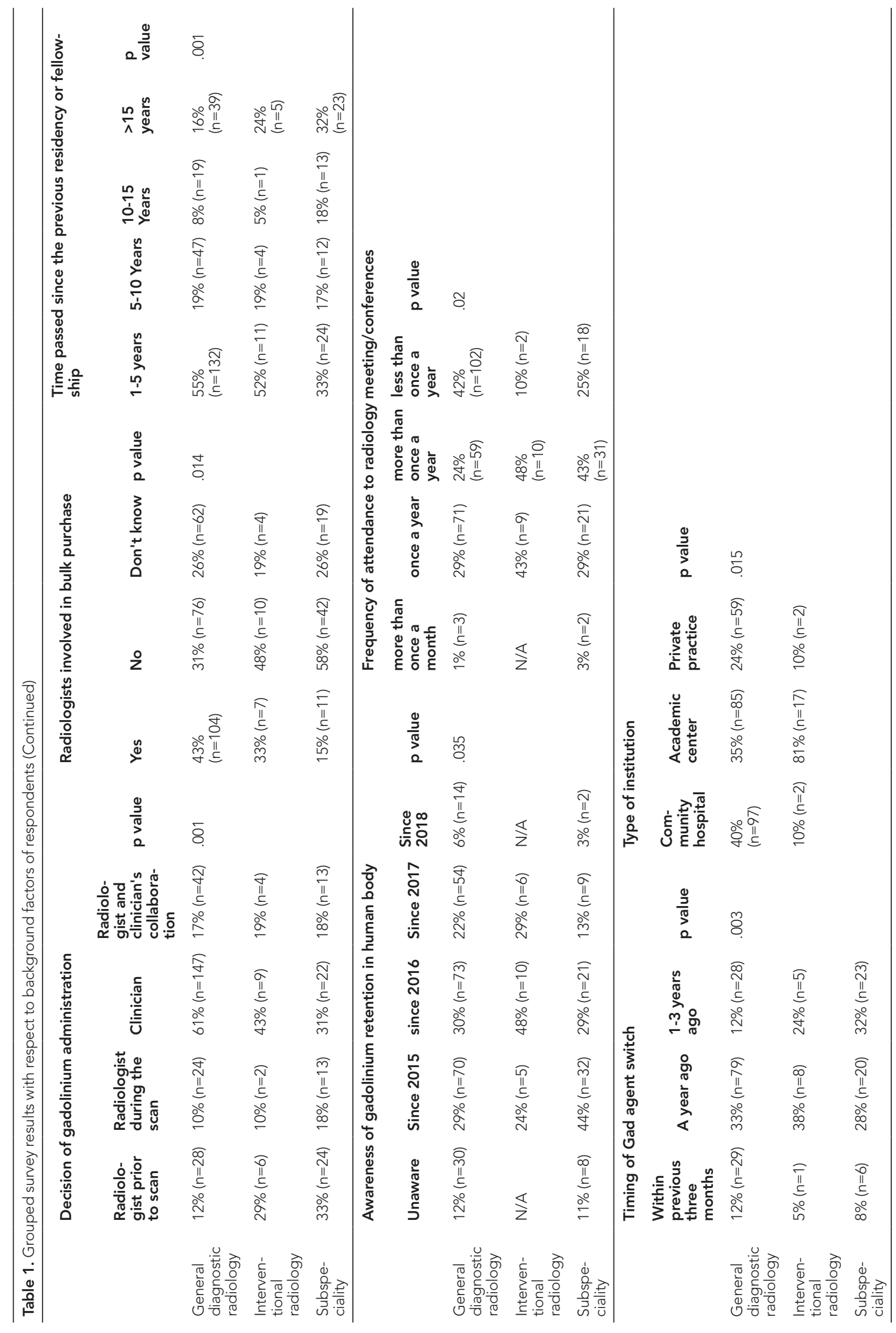




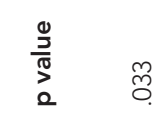

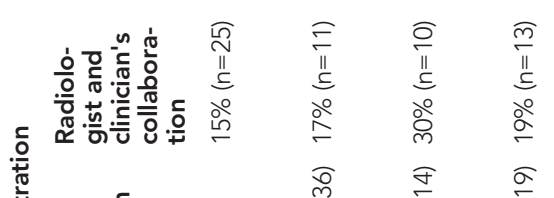

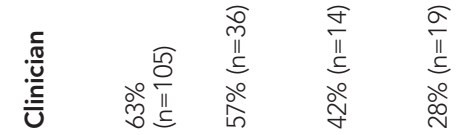

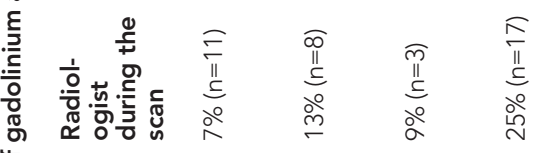

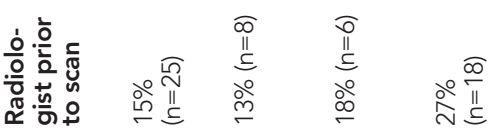

$\stackrel{\frac{0}{3}}{\frac{0}{3}} \bar{c}$

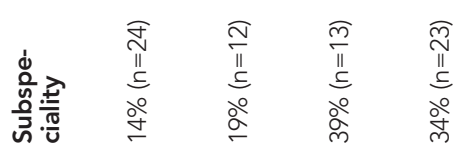

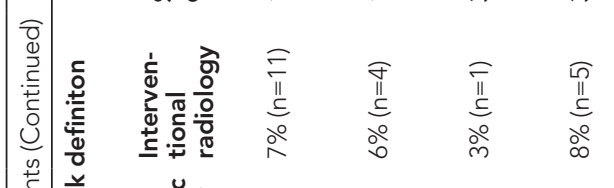

竞畜

高妾

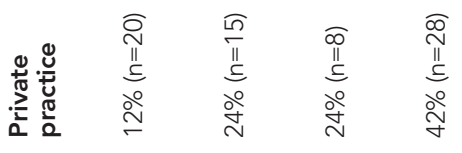

|lll

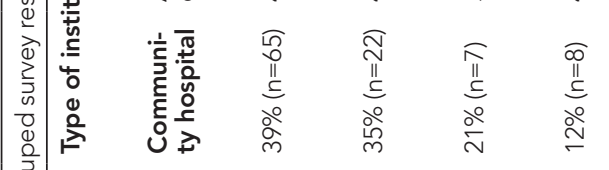

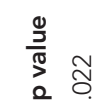

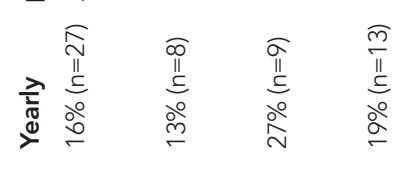

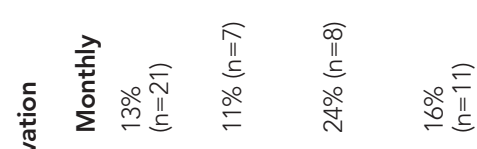

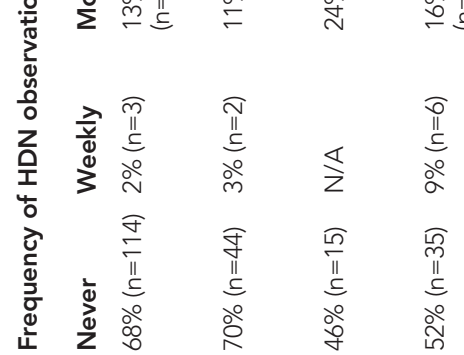

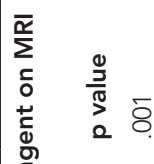

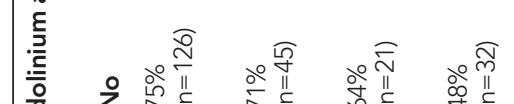

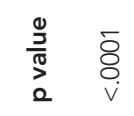

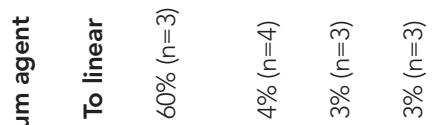

है

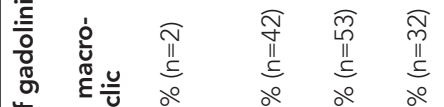

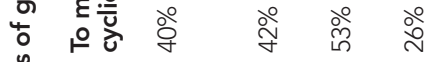

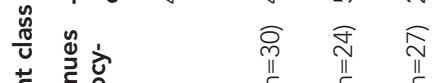

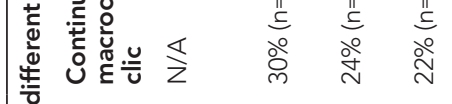

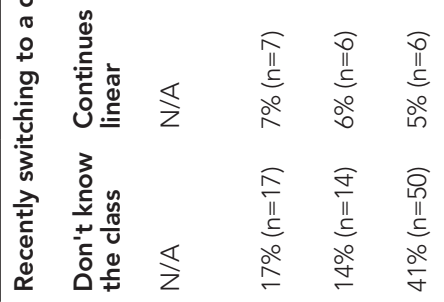

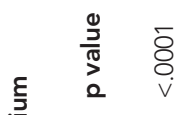

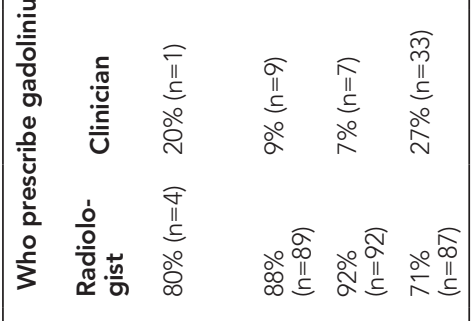

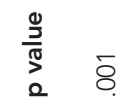

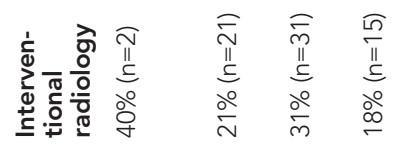

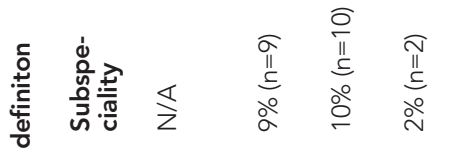

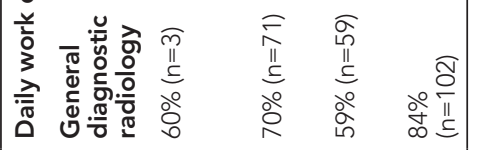

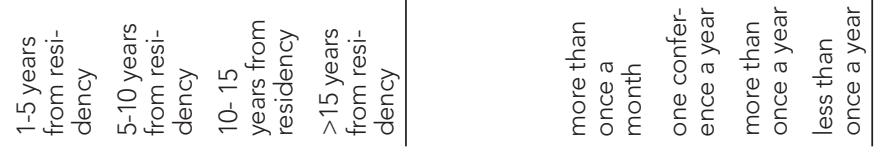


agent and had not change it in the previous three years, $39 \%(n=130)$ were using a linear gadolinium agent and switched it to a macrocyclic agent in the previous three years, $6 \%(n=19)$ were still using linear gadolinium agents, $3 \%(n=10)$ were using a macrocyclic gadolinium agent and switched to a linear agent in the previous three years. In terms of the timing of change within the previous threeyear period; $11 \%(n=36)$ switched to a gadolinium agent within the previous three months, $32 \%(n=107)$ in the previous year, $17 \%(n=56)$ within the previous three years. Thirty-six percent $(n=107)$ switched because of gadolinium retention, $26 \%(n=77)$ because of NSF risk, and $11 \%(n=33)$ switched because of the agent's cost. In terms of gadolinium deposition, 11\% ( $n=38)$ were unaware of emerging gadolinium retention data. This ratio was highest among those who attended a radiology conference less frequently than once a year (see Table 1 for details). Thirty-two percent $(n=107)$ came to know of gadolinium deposition risk in 2015, 31\% ( $n=104)$ in 2016, 21\% ( $n=69)$ in 2017, and $5 \%(n=16)$ in 2018 . Thirty-six percent $(n=121)$ had not read the statements of the following organizations about gadolinium retention. Thirty-nine percent $(n=132)$ read the American College of Radiology (ACR) and American Society of Neuroradiology (ASNR) statements, 7\% $(n=24)$ read the US Food and Drug Administration (FDA) statement, 15\% $(n=50)$ read the European Medicines Agency's (EMA) pharmaceutical risk assessment committee statement on the matter. In terms of the impact of knowledge of gadolinium retention on practitioners' clinical practice, $45 \%(n=152)$ said they decreased the amount and/or frequency of gadolinium-enhanced scans since the time that they found out about gadolinium deposition risk, while $46 \%(n=156)$ did not. Respondents were asked to rate the frequency of cases in which they faced diagnostic difficulty because of a reluctance to administer gadolinium. Twenty-two percent $(n=73)$ answered 'never', 59\% ( $n=195)$ answered 'seldom' and 19\% ( $n=63)$ answered 'frequently'. On the frequency of encountering HDN on pre-contrast MRI studies, $64 \%$ of radiologists $(n=211)$ said 'never', $18 \%$ $(n=58)$ said 'once a year', $15 \%(n=48)$ said 'once a month', $3 \%(n=11)$ said 'once a week'. While $58 \%(n=54)$ respondents did report the existence of an HDN on their final MRI reports, $42 \%(n=39)$ did not. The highest HDN observation rates were seen in academic centers (Table 1). Forty-four percent $(n=105)$ of respondents would include the generic name and amount of gadolinium agent used for a scan in their final MRI report, $56 \%(n=131)$ would not. One percent $(n=3)$ of respondents faced a medico-legal problem or a complaint by patients and/or their relatives because of gadolinium administration, 99\% $(n=330)$ did not. All three of those who had a medico-legal problem were between 1-5 years from residency.

The rate at which radiologists detected HDN was highest among academic centers, followed by private practices and community hospitals, respectively ( $p: 0.001)$, see 
Table 1 for details). Awareness of gadolinium retention was highest among academic centers and was followed by community hospitals and private practice $(94 \%, 86 \%$ and $75 \%$ respectively ( $p=0.07$ ) see Table 1 for details). Thirty-nine percent of private practice members were unaware of the class of gadolinium agent they were using as opposed to $24 \%$ in community hospitals and $19 \%$ in academic centers ( $p=0.001)$. Forty-five percent of academic centers switched from linear to macrocyclic agents and this was followed by community hospitals (39\%) and private practices $(24 \%, p=0.01)$. Unawareness rates of gadolinium deposition was inversely correlated with how frequently the physicians attended a radiology conference (22\%, $7 \%, 2 \%$ and $0 \%$ in groups with; less frequent than once a year, once a year, more frequent than once a year and once a month, respectively $(p<0.01))$.

\section{Routine MRI workflow and protocoling}

According to $53 \%(n=173)$ of respondents, the referring physician would decide whether to include post-gadolinium sequences for a given MRI scan. This practice was significantly common in community hospitals (Table 1). The remaining respondents said a radiologist would be involved in the decision-making process in the following roles: Prior to a particular scan, radiologist would decide whether gadolinium administration is needed $17 \%$, $\mathrm{n}=58$ ); at the time of a scan, after evaluating initial sequences $(12 \%, \mathrm{n}=29)$; and prior to a scan after a discussion with referring physician based on clinical indication (18\%, $\mathrm{n}=59$ ). The rate of a radiologist's role in the decision-making process of gadolinium injection was the highest among subspecialty-focused radiology practitioners and experienced radiologists (Table 1). Interestingly, private practice radiologists had higher rates of involvement in gadolinium protocoling compared to academic centers and community hospitals ( $74 \%$ versus $55 \%$ and $21 \%$, respectively $(p=0.021))$. For outpatient MRI scans, a radiologist would prescribe gadolinium in $84 \%(n=280)$, while the rest were prescribed by a referring physician $(16 \%$, $n=55)$. Thirty-eight percent $(n=128)$ of respondents were consulted in the hospital's gadolinium purchase process for inpatient services, while $36 \%(n=122)$ were not. Twenty-five percent $(n=85)$ said they were unaware of the hospital's purchase process. Twenty-eight percent $(n=95)$ of respondents were routinely testing serum creatinine levels before an MRI scan, 7\% ( $n=23)$ tested eGFR levels and $20 \%(n=68)$ tested both creatinine and eGFR levels on a routine basis. Thirty-five percent $(n=117)$ tested neither parameter and $10 \%(n=32)$ were unaware of renal function testing status prior to an MRI scan in their institution. Kidney function testing was highest in academic centers, followed by community hospitals and private practices ( $p=0.03$, see Table 1 for details). Sixty percent $(n=202)$ of participants offered agent specific (e.g. linear vs macrocyclic gadolinium) consent forms to patients prior to MRI scans, while 39\% $(n=131)$ did not. Forty-one percent
( $n=136)$ of participants recorded a cumulative dose of gadolinium administration from prior studies before undergoing an MRI scan, while 59\% ( $n=199)$ did not. The rate of recording cumulative gadolinium administration from prior studies, including outside studies, was highest by radiologists in private practice $(61 \%$ compared to $38 \%$ and $31 \%$ in academic centers and community hospitals, respectively $(p<0.0001))$. Agent specific consent acquisition was most common among private practice practitioners followed by community hospitals and academic centers $(75 \%, 59 \%$ and $55 \%$, respectively $(p<0.001))$.

\section{DISCUSSION}

Awareness of gadolinium retention has had a significant impact on practitioners' approaches to contrast enhanced MRI scans, as nearly a half of our study participants decreased the amount of gadolinium administration per scan, and/or decreased the frequency of gadolinium-enhanced scans since they became aware of the gadolinium retention risk. This stance did not show any significant association with respondents' background factors like institution, experience and practice type. Currently, the vast majority of participants in our present study use a macrocyclic agent, with more than half of them having switched to it within the previous three years (2015-2018), mostly during 2018. The rate of switching to a macrocyclic agent was highest among academic centers. This may be because they were the most concerned about gadolinium deposition, they were the heaviest users of linear agents prior to recognizing the gadolinium deposition controversy, or because of economic factors not explored by this study. Certainly the manufacturers of gadolinium agents have been marketing on the basis of reduced gadolinium deposition since the reports of HDN have arisen. In terms of reasoning, among those who switched to a different class of gadolinium, most stated they had done so because of recent gadolinium retention data, and this was followed by NSF risk and the agent's cost. Moreover, despite several published studies in high impact journals (1-30), a tenth of radiologists are still unaware of gadolinium retention issues. This ratio was highest among those who attended a radiology conference less frequently than once a year. Frequency of attendance at a scientific conference was most common amongst interventional radiology practitioners. The awareness rate of gadolinium deposition was correlated with how frequently the radiologist attended a radiology conference. This signifies that despite the ubiquity of online and offline learning tools, conventional conferences are still an important source of practitioners' update on HDN. On the other hand, observance of retained intracranial gadolinium is uncommon, as more than a half of our respondents had never noticed HDN in their daily practice, which maybe resultant of the scarcity of MRI utilization in their practice. The highest HDN observa- 
tion rates were seen in academic centers. In terms of $\mathrm{MRI}$ protocoling, in practice of more than a half of our survey respondents, ordering physicians make the decision whether to administer gadolinium at the time of the study request. This practice was very common in community hospitals. The rate of a radiologist's role in the decision-making process of gadolinium injection was the highest in private practices and among subspecialty-focused radiology practitioners and experienced radiologists. Despite the professional responsibility of radiologists in study protocoling, the present study shows that in the majority of cases, particularly in government-run and community hospitals, referring physicians are the primary decision-makers of the gadolinium necessity for a given scan (53\%). However, radiologists still determine the particular gadolinium agent to be used in the vast majority of practices (84\%), regardless of the type of institution.

Gadolinium, a rare earth metal, has been documented to remain in the human brain for as long as eleven years and possibly longer (4). It is also retained in the skin, bones and liver, along with other organs and has different chemical forms and uncertain in vivo behavior (17-22). After such gadolinium retention reports emerged, safety concerns were raised and linear agents, which deposit more frequently in tissue, were eventually suspended from the contrast agent market in many countries (9). Public attention to gadolinium retention reports increased the number of people with symptoms attributed to their gadolinium injection history, which also sparked medico-legal issues $(10,11)$. In the present study, a medicolegal case associated with a patient's gadolinium administration history was an extremely rare occasion. Although practitioners remain wary, adverse clinical outcomes of intracranial gadolinium retention have not been proved to date. In their survey study of gadolinium related symptoms, Semelka et al. reported a variety of symptoms including, but not limited to, headache and bone pain (10). However, their study suffered from selection bias, as symptoms were self-reported by patients who underwent repeated doses of gadolinium administration and attributed their symptoms to this history. Along with new clinical regulations in gadolinium applications, possible ways to decrease cumulative gadolinium exposure in chronic patients like multiple sclerosis are being investigated $(23,24)$. Gong et al. succeeded in decreasing the amount of gadolinium needed for a brain MRI by up to $10 \%$ of the regular dose by using a series of image enhancing al algorithms (25).

The present study also has critical findings in terms of radiology practice in Turkey. Participants in our study were affiliated with academic facilities, community hospitals and private practices, in decreasing order. Young radiologists were more commonly affiliated with community hospitals, possibly resulting from an ongoing Turkish gov- ernment policy of obligatory duty in underserved areas after completion of a residency program. The majority of survey respondents defined their daily basis practice as general diagnostic radiology (low percentages of subspecialty focused practice). This is in line with the radiology training landscape reported by the European Society of Radiology (ESR), which showed fellowship training was not well established in European countries when compared with North America (26). Gadolinium retention data affected the majority of radiologists in this survey. Nonetheless, in the English literature, very few studies are available on impact of emerging gadolinium retention data on daily radiology practice and gadolinium enhanced MRI exercises (27-29). Despite diversity in adopted methods and their small sample sizes, available studies' overall results are in line with our present study. In their online open survey study conducted on Radiopedia.com, Fitzgerald et al. reported that 24 of 87 (28\%) respondents made a change in their practice by either switching to a macrocyclic agent or decreasing the number of contrast enhanced MRI scans (29). This percentage is lower than our findings; however, their study was conducted at an earlier stage of gadolinium retention awareness. In an international survey study conducted on 58 neurosurgeons and neuroendocrinologists by Nachtigal et al., 28\% of respondents were unaware of gadolinium retention risk (28). In their study $11 \%$ of respondents were unaware of the class of gadolinium agent they prescribed, a mildly lower rate than our findings (28). There is also a scarcity of studies focusing on contrast enhanced MRI exercises like gadolinium protocoling, consent forms, and renal function testing. In a study conducted on 162 pediatric radiologists (mostly academic centers from the USA), $25 \%$ of respondents would not contact the clinician and thus, the ordering physician would decide the MRI protocol as far as gadolinium administration (27). In our study this rate was significantly higher (53\%). Together, our studies show that referring clinicians are deciding whether to administer contrast on MRI studies to a large extent. This may have caused unwarranted gadolinium injections (28).

More than a half of respondents in our study performed routine renal function testing prior to an enhanced MRI scan, mostly by testing serum creatinine levels. There was significant association between renal function testing and the type of institution. Academic centers had the highest renal function testing rates. In their aforementioned study, Blumfield et al. reported that $59 \%$ of their respondents required renal function testing only in selected cases (27). Two thirds of our respondents had distinct consent forms for each gadolinium class; same as the frequency of recording prior individual gadolinium administrations before undergoing an MRI scan. Prior exposure data recording was significantly higher among private practices and experienced radiologists. Recording prior administrations of gadolinium is important, as 
gadolinium retention has been shown to be dose-dependent (30).

In terms of reporting practices, more than a half of our respondents did not include the generic name and amount of gadolinium agent used for the scan in their final MRI report. Experienced radiologists had significantly higher reporting rates. More than half of those who encounter HDN would report this finding in their MRI report. Fitzgerald et al. reported that $38 \%$ of participants in their study had never seen HDN and 58\% of their respondents would report HDN in the final MRI report, in line with our present findings.

The present study was conducted on a large cohort of radiologists from Turkey, thus the findings may not necessarily reflect the worldwide situation. However, findings of the current study were comparable to that of globally conducted studies $(26,28,29)$. Because the name of institutions was not queried, the specific number of institutions participating in this study could not be quantified. Heterogeneity within the practice of a certain institution was not queried, as the study aimed to investigate the radiologists' personal stance rather than institutional practices.

\section{CONCLUSION}

Gadolinium retention publications have affected radiologists' preferences in the practice of contrast enhanced MRI scans, mostly in the form of switching to a macrocyclic gadolinium agent and decreasing utilization of gadolinium. These changes varied among radiologists by background factors such as experience in radiology, practice setting, and subspecialty training. Some of our findings about the practice of radiology in Turkey are potentially actionable. There may be a need for greater involvement of radiologists in study protocoling and gadolinium decision-making.

Acknowledgements: Authors thank survey responders for their time. We also thank Turkish Society of Radiology for sending invitation e-mails to their members.

Peer Review: Externally peer-reviewed.

Author Contributions: Conception/design of study- M.E.A.; Drafting manuscript- M.E.A., D.M.Y.; Critical revision of manuscript- M.E.A.; Final approval and accountability- M.E.A., D.M.Y.

Conflict of Interest: Authors declared no conflict of interest.

Financial Disclosure: Authors declared no financial support.

Teşekkür: Yazarlar, zaman ayırıp ankete cevap verenlere ve Türkiye Radyoloji Derneği'ne ve üyelerine davet e-postası gönderdikleri için de ayrıca teşekkür ederler.

\section{Hakem Değerlendirmesi: Dış bağımsız.}

Yazar Katkıları: Çalışma konsepti/tasarım-M.E.A.; Yazı taslağıM.E.A., D.M.Y.; İçeriğin eleştirel incelemesi- M.E.A.; Son onay ve sorumluluk- M.E.A., D.M.Y.

Çıkar Çatışması: Yazarlar çıkar çatışması beyan etmemişlerdir.

Finansal Destek: Yazarlar finansal destek beyan etmemişlerdir.

\section{REFERENCES}

1. Kanda T, Ishii K, Kawaguchi H, Kitajima K, Takenaka D. High signal intensity in the dentate nucleus and globus pallidus on unenhanced T1-weighted MR images: relationship with increasing cumulative dose of a gadolinium-based contrast material. Radiology 2014;270:834-41. [CrossRef]

2. Adin ME, Yousem DM, Kleinberg $L$, et al. Hyperintense dentate nuclei on T1 weighted MRI. Presented at the $X X^{\text {th }}$ Symposium Neuroradiologicum, Istanbul, Turkey, 2014. 0152

3. Kanda T, Osawa M, Oba H, Toyoda K, Kotoku JI, Haruyama $T$, et al. High signal intensity in dentate nucleus on unenhanced T1-weighted MR images: association with linear versus macrocyclic gadolinium chelate administration. Radiology 2015;275(3):803-9. [CrossRef]

4. Adin ME, Kleinberg L, Vaidya D, Zan E, Mirbagheri S, Yousem DM. Hyperintense dentate nuclei on T1-weighted MRI: relation to repeat gadolinium administration. AJNR Am J Neuroradiol 2015 Sep 10. [CrossRef]

5 Ramalho J, Semelka RC, Ramalho M, Nunes RH, AlObaidy M, Castillo M. Gadolinium-based contrast agent accumulation and toxicity: an update. AJNR Am J Neuroradiol 2016;37(7):1192-8. [CrossRef]

6. Kanda T, Fukusato T, Matsuda M, Toyoda K, Oba H, Kotoku $\mathrm{JI}$, et al. Gadolinium-based contrast agent accumulates in the brain even in subjects without severe renal dysfunction: evaluation of autopsy brain specimens with inductively coupled plasma mass spectroscopy. Radiology 2015;276(1):228-32. [CrossRef]

7. Tamrazi B, Nguyen B, Liu CS, Azen CG, Nelson MB, Dhall $G$, et al. Changes in signal intensity of the dentate nucleus and globus pallidus in pediatric patients: impact of brain irradiation and presence of primary brain tumors independent of linear gadolinium-based contrast agent administration. Radiology 2017;287(2):452-60. [CrossRef]

8. Adin ME, Yousem DM. Hyperintense dentate nuclei at precontrast T1-weighted MRI: Gadolinium deposition or brain irradiation?. Radiology 2018;288(2):632-3. [CrossRef]

9. Runge VM. Dechelation (Transmetalation): Consequences and Safety Concerns With the Linear Gadolinium-Based Contrast Agents, In View of Recent Health Care Rulings by the EMA (Europe), FDA (United States), and PMDA (Japan). Investigative Radiology 2018;53(10):571-8. [CrossRef]

10. Semelka RC, Ramalho J, Vakharia A, AlObaidy M, Burke LM, Jay $M$, et al. Gadolinium deposition disease: Initial description of a disease that has been around for a while. Magn Reson Imaging 2016;34(10):1383-90. [CrossRef]

11. https://gadoliniumtoxicity.com.

12. Gale EM, Atanasova IP, Blasi F, Ay I, Caravan P. A manganese alternative to gadolinium for MRI contrast. J Am Chem Soc 2015;137(49):15548-57. [CrossRef] 
13. Park, Eun-Ah, Whal Lee, Young Ho So, Yun-Sang Lee, Bongsik Jeon, et al. Extremely small pseudoparamagnetic iron oxide nanoparticle as a novel blood pool T1 magnetic resonance contrast agent for $3 \mathrm{~T}$ whole-heart coronary angiography in canines: comparison with gadoterate meglumine. Invest Radiol 2017;52(2):128-33. [CrossRef]

14. Vijayasarathi A, Kharkar R, Salamon N. Strategies for patient-centered communication in the digital age. Curr Probl Diagn Radiol. Epub 2018 Jun 1. [CrossRef]

15. Gefen R, Bruno MA, Abujudeh HH. Online portals: gateway to patient-centered radiology. AJR Am J Roentgenol 2017;209(5):987-91. [CrossRef]

16. Oren O, Kebebew E, loannidis JP. Curbing unnecessary and wasted diagnostic imaging. JAMA 2019;321(3):245-246. [CrossRef]

17. Guo BJ, Yang ZL, Zhang LJ. Gadolinium deposition in brain: current scientific evidence and future perspectives. Front Mol Neurosci 2018;11:335. [CrossRef]

18. Zhao J, Zhou ZQ, Jin JC, Yuan L, He H, Jiang FL, et al. Mitochondrial dysfunction induced by different concentrations of gadolinium ion. Chemosphere 2014;100:194-9. [CrossRef]

19. Abraham JL, Thakral C. Tissue distribution and kinetics of gadolinium and nephrogenic systemic fibrosis. Eur J Radiol 2008;66(2):200-07. [CrossRef]

20. Ray DE, Cavanagh JB, Nolan CC, et al. Neurotoxic effects of gadopentetate dimeglumine: behavioral disturbance and morphology after intracerebroventricular injection in rats. AJNR Am J Neuroradiol 1996;17(2):365-73.

21. Behzadi AH, Faroog Z, Zhao Y, Shih G, Prince MR. Dentate Nucleus Signal Intensity Decrease on T1-weighted MR Images after Switching from Gadopentetate Dimeglumine to Gadobutrol. Radiology 2018;287(3):816-23. [CrossRef]

22. Adin ME, Yousem DM. Disappearance of T1-weighted MRI hyperintensity in dentate nuclei of individuals with a history of repeat gadolinium administration. Radiology 2018;288(3):911. [CrossRef]
23. Karimian-Jazi K, Wildemann B, Diem R, Schwarz D, Hielscher T, Wick W, et al. Gd contrast administration is dispensable in patients with MS without new T2 lesions on follow-up MRI. Neurol Neuroimmunol Neuroinflamm 2018;5(5):e480. [CrossRef]

24. Eichinger $P$, Schon $S$, Pongratz $V$, Wiestler $H$, Zhang $H$, Bussas $M$, et al. Accuracy of unenhanced MRI in the detection of new brain lesions in multiple sclerosis. Radiology 2019:291(2):429-35. [CrossRef]

25. Gong E, Pauly JM, Wintermark M, Zaharchuk G. Deep learning enables reduced gadolinium dose for contrastenhanced brain MRI. J Magn Reson Imaging 2018;48(2):33040. [CrossRef]

26. European Society of Radiology. Radiological Training Programmes in Europe: EAR Education Survey - Analysis of Results. 2004 EAR Education Committee. [accessed 2016 May 8]. Available from: URL: https://www.myesr.org/html/ img/pool/ESR_brochure_05.pdf

27. Blumfield E, Moore MM, Drake MK, Goodman TR, Lewis $K N$, et al. Survey of gadolinium-based contrast agent utilization among the members of the Society for Pediatric Radiology: a Quality and Safety Committee report. Pediatr Radiol 2017;47(6):665-73. [CrossRef]

28. Nachtigall LB, Karavitaki N, Kiseljak-Vassiliades K, Ghalib L, Fukuoka H, Meyer LT, et al. Physicians' awareness of gadolinium retention and MRI timing practices in the longitudinal management of pituitary tumors: a "Pituitary Society" survey. Pituitary 2019;22(1):37-45. [CrossRef]

29. Fitzgerald RT, Agarwal V, Hoang JK, Gaillard F, Dixon A, Kanal E. The impact of gadolinium deposition on radiology practice: an international survey of radiologists. Curr Probl Diagn Radiol 2019;48(3):220-3. [CrossRef]

30. McDonald RJ, McDonald JS, Kallmes DF, Jentoft ME, Murray $D L$, Thielen $K R$, et al. Intracranial gadolinium deposition after contrast-enhanced MR imaging. Radiology 2015;275(3):772-82. [CrossRef] 


\section{Appendix 1: Survey questions.}

This survey is designed solely for scientific research purposes and there is no financial relation with any company, institution or organization. The survey does not require any personal information. Please do not participate in the survey if one full year has not passed since your residency and/or fellowship training. To be part of this study, your current radiology practice should include MRI studies, please do not participate otherwise.

1-What kind of institution do you work for?

2-Which of the following best describes your daily radiology practice?

3-Who decides whether an MRI examination in your institution will be performed with or without IV contrast agent application?

4-If gadolinium is prescribed to patients before scan as part of your practice, who prescribes MR contrast agent in your hospital?

5- If contrast agents are provided by hospital itself, does hospital management consult radiologists before making bulk purchases of MRI contrast agent?

6-Do you routinely check kidney function before your patients are given gadolinium?

7-Do you question your patients' exposure and amount of gadolinium before the contrast-enhanced MRI is performed?

8- Are you aware of molecular classes (linear or macrocyclic) of gadolinium agents? If so, have you changed the contrast agent you have prescribed in the previous three years?

9-If yes, why?

10- If yes, when did you change it?

11-How often do you attend to scientific conferences/meetings?

12- How many years ago did you complete your residency/fellowship training?

13-Have you heard that gadolinium accumulates in the brain after a certain amount of exposure in some individuals with a history of contrast-enhanced MRI scans? If so, when did you first get to know it? (Please jump to the $15^{\text {th }}$ question if your answer to the first part of this question is No).

14-Did you change the amount or frequency of contrast agent application after being aware of gadolinium accumulation in the human brain?

15-Do you include in your MRI report the name and amount of contrast material given to the patient during scan?

16-Do you have a drug-specific consent form for the patients and/or relatives before administration of a contrast agent?

17- Have you ever observed a hyperintense dentate nucleus at your routine clinical MRI readings? If so how often do you observe?

18-Do you report hyperintense dentate nucleus in your MRI report?

19-Are you aware of the following medical institutions' announces about gadolinium accumulation in the brain? (click all that apply).

20-Did you experience any diagnostic difficulties because you hesitated to use contrast media in your clinical practice?

21-Have you received any feedback from your patients about the accumulation of gadolinium in the brain or have you had any medical-legal problems? 